Molnár Ferenc Tamás

\title{
A „NAGY TESTVÉR FIGYEL! - SZABADULJ KI A KÖNYVTÁRBÓL!” PROGRAM MEGVALÓSULÁSA ÉS EREDMÉNYEI
}

\section{Absztrakt}

A tanulmány a Nagy Testvér figyel! - Szabadulj ki a könyvtárból! könyvtárhasználati program megvalósulását és eredményeit mutatja be. A középiskolások körében jóval kevesebb olvasót vélünk felfedezni, mint a fiatalabb vagy idősebb korosztálynál. A kutatásom hipotézise, hogy egy könyvtári szabadulószobával a középiskolás korosztályt könnyebben becsalogathatjuk a könyvtári térbe, mindezzel fejleszthetjük az információs műveltségüket és a közösségben való együttműködésüket. Az az álláspont, miszerint a fiatalok nem szeretnének új ismereteket megszerezni, véleményem szerint nem igaz. Napjaink oktatási rendszere hasonlít Madách Imre tragédiájának Falanszter színére, az egyéniséget elnyomja, merev, és fenntartja az egyenlőség látszatát. Ellenben egy mai középiskolás mindenben az élményt igyekszik keresni, amit napjaink oktatási rendszerében nem igazán tapasztalhat meg, inkább a lexikális tudás megtanulása és annak számonkérése a cél és nem a megértés során történő egyéni információszerzés. Egy adott témában akkor lesz képes a diák kritikusan gondolkodni, ha a tanulás során kialakul a kritikai attitűd a tanulmányok vagy a világ dolgai iránt. Igyekeztem egy olyan könyvtárhasználati szabadulószoba programot kidolgozni, amely egy közkönyvtári térben is megvalósulhat játékos, szórakoztató módon. Az esettanulmány során számos kutatási kérdés, probléma merült fel. Napjaink oktatási rendszerében háttérbe szorul a könyvtárhasználat és a digitális írástudás fejlesztése, ezért egy olyan programot kívánok bemutatni módszertani megalapozással és fejlődéstörténettel, amely játékos, élményszerű módon növeli az említett területeken a tudásszintet. A tanulmány a program fejlesztéséhez szükséges elmélet megalapozására, valamint a tesztelési eredmények elemzésére és értékelésére fókuszál.

Kulcsszavak: szabadulószoba; információkeresés; információs írástudás

\section{Bevezetés}

Korszakunk a folyamatos változásról és az adaptálódásról szól. Új nemzedékek és velük együtt új elvárások, kihívások és lehetőségek jelennek meg a világ színterein. A könyvtár sem kivétel. Funkciója, szerepe is folyton változik. Bár látszólag a „nyugati” könyvtárak az elmúlt évszázad történelmi eseményei miatt lépéselőnyben vannak, ez azonban nem azt jelenti, hogy mi a volt keleti-blokk országaiban szükségszerűen le vagyunk maradva. Tendencia, hogy a könyvtár ma már nem csak dokumentumokat gyűjt, őriz, katalogizál, szolgáltat - hanem közösségi programokat is szervez, segítséget nyújt az önművelődésben, a világhálón való tájékozódásban. Vannak-e ilyen programjaink? Vannak. (Lásd.: A Fővárosi Szabó Ervin Könyvtár az EFOP-3.3.3-VEKOP-16-2016-00001 
„Múzeumi és könyvtári fejlesztések mindenkinek” pályázati konstrukció keretében „Az én könyvtáram” című kiemelt projekt számára elkészült kiadványokat: Béres, 2019; Fehér \& Koglerné Hernádi 2019a, 2019b; Hajdu \& Béres, 2019)

A szakma már rájött, hogy nem minden múlik a pénzen, az épület korszerűségén, az állomány gazdagságán. Szinte a semmiből is lehet érdekes, szórakoztató és hasznos könyvtári programokat létrehozni. A szándék és a lehetőség sokszor meg is van rá, az érdeklődés nem mindig. Evidencia, hogy a különböző korcsoportokat különbözőképpen lehet megszólítani, bevonni egy intézmény életébe. Kiemelt lehet napjainkban a könyvtár használatának oktatása is. Két speciális korcsoport is problémába ütközhet a gyakorlati használat során. A nyugdíjas generáció számára a számítógépes környezet, a modern adatbázisok idegenek és ijesztőek lehetnek. A fiatalabbak viszont, akik már beleszülettek a számítógépes hálózatok világába, talán a klasszikus (szigorú) könyvtári rendszerben ismerik ki magukat nehezebben. Írásomban elsősorban a fiatalokra koncentrálok.

Érezzük, hogy az oktatásban is szükséges lenne változtatni, a tanárokat azonban kötik a tantervek és a törvényi szabályozás. Abban ugyan konszenzus van, hogy jó lenne más szemszögből is bemutatni a tananyagot, hiszen a 19-20. századi módszertannal már a Zgenerációt (1996 után születettek) sem tudták úgy oktatni, hogy a tanulás ne teher, hanem élmény, valami új felfedezése legyen. Az alfa generációnál (2010 után születettek) pedig nagy a valószínűsége, hogy a tudásátadás csak akkor lesz sikeres, ha változtatunk módszereinken is. (Megjegyezhetjük a tanítás ilyen formái régebben sem jelenthettek feltétlenül élményt a diákoknak, erről tanúskodik a világirodalom számos diákregénye is.) Hogy a közoktatásban ez a változás mikor fog lezajlani, nem tárgya jelen írásomnak. Arra azonban rávilágíthatunk, hogy a könyvtárost nem kötik ilyen szigorú szabályok. A könyvtárhasználat oktatásában tehát bátran lehet kísérleti módszereket is kipróbálni, ahogy teszik is ezt a kollégák szerte az országban. Léteznek könyvtártúrák, különböző online lehetőségek, könyvtári programok. Egy olyan játékot szerettem volna megalkotni, aminek során a résztvevők megismerik a könyvtárat (beleértve a könyvtár épületét és a gyűjteményben való keresés logikáját is), továbbá kénytelenek kézbe venni fizikailag is a nyomtatott könyveket, ugyanakkor emellett a modern kor technikáit is használhatják.

\section{Elméleti háttér}

Programunk kidolgozása során számos - már létező - pedagógiai-, pszichológiai-, könyvtártudományi elmélet befolyásolt minket. Túlzás lenne azonban azt állítani, hogy ezeket tudatosan alkalmaztuk a program első verzióinak kidolgozása során. Elsősorban olyan megoldást kerestünk, ami számunkra izgalmas és érdekes lenne. Az első tesztek azonban rámutattak arra, hogy olyan generációs különbségek vannak köztünk és az akkori célcsoportunk (a végzős gimnazisták) között, ami teljesen más megközelítésmódot követelt meg. Mint azt a későbbiekben látni fogjuk, nemcsak a program jellege, de a módszertana is többször változott, míg végül egy „könyvtárhasználati szabadulószobát” alkottunk meg. Először még mi magunk is bizonytalanok voltunk abban, hogy szabad-e ezt „szabadulószobának” hívni. Jobban emlékeztetett a klasszikus általános iskolai akadályversenyekre, ahol a fizikai térben kell A-pontból B-pontig eljutni úgy, hogy közben 
különféle játékos feladatokat kell megoldani. Alapvetően bizonytalanságunk elsődleges oka az volt, hogy az általunk ismert „szabadulószobák” nem ilyenek. Teljesen más eszközökkel, feladattípusokkal operálnak, teljesen más térben valósulnak meg. Bár a szabadulószobát sokan magyar invenciónak tartják, ennek ellenére igazán jó, és számunkra is hasznos módszertani leírások nem kerültek elő. Ennek főként az lehet az oka, hogy a szabadulószobák többnyire üzleti vállalkozások formájában működnek, így nem füződik érdekük módszertani titkaik felfedéséhez.

A Társadalmi Befogadás Szakkollégiumban az elmúlt tanévek során két különböző típusú szoba is megvalósult. (A másik a Fekete Csönd című program) A 2020 októberében tartott kerekasztal beszélgetésünk - amelyen részt vett Markal Roland (ParaPark) és Pintér Csaba (Specko Pécs) is - megerősített bennünket abban, hogy a hazai üzleti alapon működő szobák legtöbbje licenc alapján megy. Minimálisan alakítják csak őket a helyi környezethez, jól kipróbált, „kész” játékokat kapnak az üzemeltetők. Kevés helyen találhatunk saját fejlesztést. (Pl. Kolozsváron) A létező „állandó” játékok többsége pusztán időtöltést garantál, turisztikai szempontból hasznos, esetleg csapatépítésre (vagy éppen bomlasztásra...) alkalmas, viszonylag kevés a speciális tematikájú, konkrét céllal létrehozott program. A mi vállalkozásunk éppen attól volt más, hogy nem követtük a klasszikus szobák mintáját. Nem csak azon van a hangsúly, hogy a játékosok a feladatokat megoldják, az is a feladat része, hogy miként tudják megoldani azokat. Jellemzően nem fizikai, ügyességi próbákat kapnak. Nem elég „valahogy” kinyitni egy táskát, működésre bírni valamit, hanem információkat kell megkeresni az adott problémával kapcsolatosan. Adott térben, adott eszközökkel, adott idő alatt.

A játék során fontos szerepet kap az információs- és médiaműveltség, a digitális írástudás, valamint ezek elméleti háttere is. Napjainkban az az ember, aki nem használja az internetet, sok mindenből kimarad. Jelenleg az internetet hozzávetőlegesen 4,7 milliárd ember használhatja a világon (Internet Live Stats, 2020). Ez a szám 1 milliárddal több, mint amit Fromann Richárd Játékoslét című könyvében említett 2016-ban (Fromann, 2017). Az információs társadalom megköveteli az IKT eszközök (pl.: okostelefon, laptop, tablet) használatát, hiszen anélkül nem lehet elérni az internetes tartalmakat. A becslések szerint évente közel 1,5 milliárd okostelefont adnak el a világon, ami napi szinten több mint 3,5 millió készüléket jelent. A „hálózat” egyre nagyobb szerepet kap a mindennapjainkban, nem csak a híreket olvassuk már rajta, hanem a bevásárlást, a hivatalos ügyeket is ott intézhetjük. Ezért azok a személyek, akik az IKT eszközöket nem tudják jól használni, olykor hátrányba kerülnek és kirekesztődnek. (Fromann 2017) A 2000-es évek elején megjelent digitális bennszülött - digitális bevándorló dichotómia lecsengeni látszik (Prensky, 2001; Koltay, 2016). Az elmúlt évek tapasztalatai bizonyítják, hogy a bennszülött felhasználók sem feltétlenül képesek kihasználni az adott informatikai rendszer előnyeit. Sőt, éppen ellenkezőleg olykor a „fokozatosság hiánya” miatt képtelenek átlátni azok működését. Előnyük, hogy beleszülettek a digitális korba, egyben hátrányuknak is tűnik. Talán az is bebizonyosodott - saját tapasztalataink alapján mindenképpen - hogy a korábbi optimista és pesszimista (jövő)képek (Tóth-Mózer, 2013) valójában nem egymást kizáróan, hanem egymással párhuzamosan is értelmezhetőek. Az elmúlt hónapok tapasztalatai alapján kimondhatjuk, 
hogy a "generációba” sorolás is durva általánosítás az informatikai hozzáértést és hozzáférést illetően. A pandemia miatt villámgyorsan bevezetett online/digitális oktatás során bebizonyosodott, hogy még csak megyei vagy járási szinteken sem lehet „általánosítani” (Hermann, 2020). Egy korábbi felmérés adatai szerint is rosszul állunk az iskolai digitális eszközparkok tekintetében. (EU, 2019) Az eszköz pedig alapfeltétele annak, hogy az információs írástudás oktatása megvalósulhasson. Az 1970-es években Paul Zurkowski alkotta meg az információs írástudás fogalmát (Zurkowski, 1974). Azóta számos definíció született meg az információs írástudással kapcsolatban (Z. Karvalics, 2012; Koltay, 2016). Varga Katalin három megfogalmazást sorakoztat fel: Az egyik fogalom megalkotója az Amerikai Iskolai Könyvtárosok Egyesülete (AASL): „az információs műveltség - az információ megtalálásának és felhasználásának képessége az egész életen át tartó tanulás alapköve”. (Varga, 2008) Az információs műveltség összetevői: „az információs műveltséggel bíró diák hatékonyan és eredményesen keresi meg a szükséges információt, kritikusan és kompetensen értékeli azt, pontosan és kreatívan használja fel. Az egyénnek rendelkeznie kell információkeresési stratégiákkal és a kritikai gondolkodás képességével egyaránt, hogy a mindennapi élet problémáit újszerűen tudja megoldani a válogatott, szintetizált és kritikusan értékelt információ segítségével." (Varga, 2008) Továbbá az Amerikai Könyvtárosok Egyesülete (ALA) által megalkotott definíció napjainkban is megállja a helyét: „Az információs műveltség azt jelenti, hogy az egyén felismeri, mikor van szüksége információra, és képes megtalálni, értékelni, valamint hasznosítani azt. Az információs műveltséggel rendelkező személy megtanult tanulni." (Varga, 2008) McKenzie meghatározása szerint az információs műveltséggel bíró egyén képes sikereket elérni (megtalálja a releváns információt, rendszerezi és válogat belőle), értelmezni (az adatokat tudássá, véleménnyé és meggyőződéssé konvertálja), valamint új eszméket alkotni (új belső meggyőződésekre jut) (Varga, 2008).

Könnyen elveszhetünk az információs szmogban. Az interneten nem csak a releváns, számunkra hasznos információk lelhetőek fel, hatalmas a zaj is. A kereső-motorok nem feltétlenül a klasszikus könyvtárosi szemlélet szerint sorolják be a találati listákba a relevánsnak ítélt weboldalakat. A mély web, a képi információk továbbra is nehezen kereshetőek. Az adatbázisok, katalógusok olykor eltérő logika szerint müködnek. Ráadásul a technológia is folyamatosan változik. Nem elég „egyszer megtanulni”, hiszen egy-egy nagyobb eszközfejlesztés után a weboldalak is olykor teljesen átalakulnak. Időtálló „tankönyvet” is nehéz írni gyakorlati példákkal (Ungváry \& Vajda, 2002). Az internet tartalmát nem ellenőrzik, hiszen ez lehetetlen vállalkozás lenne. Ebből kifolyólag nagyon sok az álhír és nem releváns információ (zaj). Nagyon sok esetben pedig egy-egy funkció csak azért létezik, mert divatos, s nem azért, mert hasznos. Az információs műveltséggel rendelkező személy képes felismerni a számára releváns információt. Ismételten hangsúlyozom: az, hogy egy személy okoseszköz/számítógép felhasználó, még nem jelenti azt törvényszerűen, hogy megfelelő információs műveltséggel is rendelkezik.

Joggal merül fel a kérdés: Az iskolában hol kap helyet az információs műveltség oktatása? Általánosan mondható, hogy még mindig az információ megtanulása a „cél” és nem az információ keresésének elsajátítása. Sok helyen tapasztaljuk - Bibliai hasonlattal 
élve - hogy a tanuló halat kap csak és nem hálót. Nincs rákényszerítve, hogy a számára szükséges információkat saját maga keresse meg, emelje ki a lényeget, értelmezze, és szintetizálja. Éppen ezért a non-formális, de leginkább az informális tanulás színterein valósulhat meg leginkább ezen tudások, készségek elsajátítása (Coombs, Prosser \& Ahmed, 1973; Dippold 2013; Csík 2018, 2020).

Milyen módszerekkel valósulhat ez meg a leghatékonyabban? Ha természettudományos megközelítésben vizsgáljuk a tanulást, akkor érdemes Freund Tamás - több helyen is elhangzott - ide vonatkozó gondolatát felidéznünk. „[...] a hatékony tanulás kulcsa a belső világ impulzusainak társítása a külvilági információcsomagokkal a tárolási folyamatok során.” (Freund, 2006) Vagyis a tanulás akkor hatékony, ha valamilyen érzelmi kapcsolat is létrejön. Freund szóhasználatával élve a katarzis a fontos. Ő a művészetet emeli ki, de véleményük szerint a játék is ugyanezt a célt szolgálhatja. Kellő időt kell hagyni az információ befogadásához is, hiszen az információrobbanás miatt az agyunkat nagyon sok információ éri el. Voltaképpen erre a jelenségre épít az élményalapú oktatás is. A gamifikáció - vagy más néven játékosítás célja, hogy az általában monoton és unalmas tanulási folyamatokat érdekesebbé és eredményesebbé tegye (Fromann \& Damsa 2016). A tanuláshoz lazábban kapcsolható játékosabb tevékenységeket végezve az agynak marad ideje pihenni, feldolgozni a megszerzett tudást is. Nevezhetjük játékalapú tanulásnak, gamifiációnak, edutainmentnek, a lényeg, hogy az új ismeretek megszerzése valamilyen szórakozási forma közben történik meg. Az élményalapú oktatás egyik fő mozgató rugója lehet a flowelmélet. Megalkotója Csíkszentmihályi Mihály Széchenyi-díjas magyar-amerikai pszichológus. A flow-nak (áramlat) gyakorlatilag a „tökéletes élmény” az alapja, amikor annyira feloldódunk egy tevékenységben, hogy minden más eltörpül mellette. Ez motivációt ad. A cselekvés többé már nem munka, hanem élmény és szórakozás (Csíkszentmihályi, 1991). A Flow-élmény a szabadulószobák alapja is. A játékos élvezi a játékot, sőt akár később is visszavágyik. Esetünkben pl. egy szabadulószoba többféle élményt nyújthat. Esztétikai élmény, mikor egy adott kor a játékos elé tárul. (pl. ha egy szobát korabeli bútorokkal, plakátokkal rendezünk be). A flow akkor jelenik meg, amikor egy bizonyos cél érdekében erőfeszítést teszünk - legyen az fizikai vagy szellemi - de nem érezzük, hogy megerőltető lenne. Továbbá fontos az egyértelmű cél megléte, mint például esetünkben a feladatok megoldása és a szabadulás. Ebben az állapotban az Én-tudat háttérbe szorul és gyakran az egyén az időérzékét is elveszíti (Mérő, 2010).

Az általam megalkotott szabadulószobának alapját képezi a közösségi tanulás. Ennek elméletét Etienne Wenger dolgozta ki a „gyakorlat közösségeit“ tárgyaló írásában (Wenger, 1998) Wenger úgy gondolja, hogy a közösségi tanulás jóval hatékonyabb, mint az egyéni tanulás, hiszen a közösségben képesek egymást motiválni a tagok egy cél érdekében. Az új ismeret megszerzésénél hajtóerő lehet a csoporttagok tudásszintje is, hiszen egymástól is képesek tanulni. (Wenger, 1998).

Hazánkban gomba módra szaporodnak a különféle társasjáték-körök, társasjátékklubok, melyek nagyon népszerűek a fiatalok körében. Természetesen itt nem a klasszikus, „régi”, „egyszer játszható” táblajátékokra vagy a sakkra kell gondolni, hanem a 
modern, nyugati játékokra. Ezek főbb ismérve, hogy nincs kétszer ugyanolyan szituáció. Sok csak csapatban játszható és épít a játékosok közti interakciókra is.

Összegezve, saját programunkat úgy próbáltuk kialakítani, hogy az hasson az érzelmekre, játékos legyen, építsen az egyének közti interakcióra és személyes kapcsolatra. Az érzelmi hatás azonban nézetünk szerint nem feltétlenül csak a pozitív hatásokat kell, hogy jelentse. Egy szabadulószobában sok negatív hatás érheti a játékost. Egyik ilyen lehet a „bezártság” ténye és a „megfelelési kényszer”, hiszen csak akkor tudnak „kiszabadulni”, ha a rájuk nehezedő feladatokat megoldják. A versenyhangulat - hogy a játékosok idő előtt kiszabaduljanak - adrenalint szabadít fel, ugyanakkor tovább nehezítheti a játékot, hogy konfliktushelyzetek fordulhatnak elő a játékostársakkal. Ezek mind értelmezhetőek negatív hatásként is, ugyanakkor hatásukat nézve pozitívak is lehetnek. Az általunk megalkotott program nem tanít didaktikusan könyvtárhasználatot és információkeresést, de rámutat a hiányosságokra és a hibákra. A koncepció fontos része, hogy a résztvevők a játék során saját maguk jöjjenek rá ezekre, tehát ne harmadik fél szembesítse őket hibáikkal.

\section{Tervezés és megvalósítás}

A következőkben arról a programról írok, amit az Országos Könyvtári Napok keretében valósíthattam meg Kóczián Zoltán Gergely közreműködésével. Összefoglalom, hogy milyen tapasztalataink voltak, miképp tudtak érvényesülni az elméleti szempontok a gyakorlatban. Előzményként említeném meg saját középiskolai élményemet, amikor George Orwell műveiből tarthattam órát diáktársaimnak. Ez meghatározó élmény volt számomra, így amikor az egyetemen Koller Inez kommunikációelmélet óráján egy fiktív könyvtári program kommunikációs tervét kellett kidolgozni, adta magát az ötlet, hogy ezzel a témával foglalkozzunk. Ahhoz, hogy egy fiktív program kommunikációs tervét megtervezzük, ki kellett dolgoznunk nagy vonalakban magát a fiktív programot is. Eredetileg ez egy több fordulós, egész nyáron át tartó, interaktív, olvasást- és könyveket népszerűsítő program lett volna. Ezt a tervet egy tanóra keretében prezentáltuk a Csorba Győző Könyvtár Kapcsolati Csoportjának, amelynek tagjai, Pajor Zsófia és Szeifer Csaba láttak benne fantáziát. Lehetőséget kaptunk tőlük, hogy tesztelhessük a program egyes elemeit élesben is. Az Elképzelt Világok fantázianevű programunkat tudatosan úgy alakítottuk ki, hogy kellő mozgásteret adjon különféle irodalmi témák feldolgozásához. A cél az volt, hogy komplex, már létező fantáziavilágok mentén hozzuk közelebb a fiatalokhoz az általunk minőséginek vélt irodalmi alkotásokat. Az Apáczai Csere János Nevelési Központ középiskolás diákjai közt végzett - nem reprezentatív - felmérésünk eredménye azonban változtatott a terveinken. Kiküldtünk a diákoknak egy teszt feladatlapot és kipróbáltuk az általunk megálmodott feladatok némelyikét. Azt tapasztaltuk, hogy a beérkezett megoldások nyitott kérdéseire többnyire a Wikipédiáról ollóztak be válaszokat. Vagyis nem sikerült elérnünk, hogy önálló, saját gondolatokat fogalmazzanak meg. A könyvtáros kollégák tanácsára és kérésére a tematikát meghagyva, de a formátumot és a módszertant teljesen megváltoztatva dolgoztunk tovább a projekten. Ennek eredménye lett az Elképzelt Világok 2.0 - A Nagy Testvér figyel! 
elnevezésű szabadulószoba. Az első játék lebonyolítása nem volt egyszerű és tökéletes sem. Egy klasszikus többfordulós tanulmányi versenyre hasonlító program teljesen más hangulatú, mint egy szabadulószoba. Más fajta feladatokat jelent és más előkészületek szükségesek hozzá. Végül egyetlen feladat, egy keresztrejtvény élte túl a konverziót. A megfejtését használtuk fel jelszóként, ami a „kulcs” volt a kijutáshoz. Eredetileg egy több szálon futó, izgalmas történetet kreáltunk, ami magába olvasztott elemeket az 1984, az Állatfarm, a Fahrenheit 451 című regényekből, de a feladatokhoz felhasználtunk karaktereket a Gulliverből és Verne regényeiből is. Sokat merítettünk a szerepjátékokból, illetve a „hide and seek” jellegű „nyomozós” számítógépes játékokból. A Társadalmi Befogadás Szakkollégium keretén belül az V. Jövő-kép Workshopon lehetőségünk volt tesztelni a koncepciót és a feladatokat. A kivitelezésben részt vett Kóczián Zoltán Gergely, segítőként Hegedűs Péter, Marton Lídia, Rácz Nikolett könyvtáros, illetve könyvtárostanár hallgatók. A teszt nehézségét elsősorban az okozta, hogy alapvetően egy könyvtárba tervezett programot kellett nem könyvtári helyszínen, kvázi laborkörülmények között, egy teremben bemutatnunk. Formailag itt álltunk legközelebb a klasszikus szabadulószobához. A játék ezen verziójában arra helyeztük a hangsúlyt, hogy képesek-e megtalálni a résztvevők a sok felesleges, haszontalan információ között a valóban lényegeset. A kvázi steril termet telehordtuk az 1984-re utaló plakátokkal, vittünk be néhány könyvet is, de hiányzott a díszlet, a „jelmezek”, a látványvilág számos eleme. Hiányzott egy „működő könyvtár” teljes eszköztára is. Ez jelentősen megkötötte a kezünket. A játékmenetnek voltak kisebb-nagyobb zökkenői, ugyanakkor a visszajelzések bizakodásra adtak okot. A 11. osztályos diákok közül - akik korábban tesztelték a tervezett tanulmányi verseny feladattípusait - többen eljöttek a szabadulószobára is, s ez sokkal jobban tetszett nekik.

Lehetőséget kaptunk arra, hogy a programot - immár könyvtári környezetben - a 2019-es Országos Könyvtári Napok keretében, a Csorba Győző Könyvtár hivatalos rendezvényeként valósítsuk meg. Ez a verzió az Elképzelt Világok 3.0 - A Nagy Testvér figyel!: Szabadulj ki a könyvtárból! fantázianevet kapta. A keresztrejtvény feladatot drasztikusan átvariáltuk. Nem arra kérdeztünk rá, hogy ki írta az adott művet, hanem például csak annyit jeleztünk, hogy „egy vezetéknevet keresünk”, s a megoldáshoz információmorzsákat adtunk. Erre a változtatásra azért volt szükség, hogy a műveltségbeli eltérések ne befolyásolják a játékot, és valóban az információkeresés kapja a nagyobb hangsúlyt. A résztvevőnek nem kellett tudnia a megoldást, elég, ha tudta, hogy miként lehet megtalálni azt. Annak érdekében, hogy a játék még izgalmasabb legyen, minden kérdéshez több úton is meg lehetett találni a választ. Az új verzióban igyekeztünk teljeskörűen kihasználni a működő könyvtár adta lehetőségeket. A kérdéseket például konkrét könyvekbe/könyvekhez rejtettük el. A könyvek megtalálása is a feladat részét képezte. A bezárt szobából átkerültünk egy fizikailag is tágasabb térbe, nagyobb mozgásteret kaptak a játékosaink. A nagyobb térben a „,sok véletlenszerűen elrejtett apró nyom" helyett választottuk a logikusan felépített, vezetett játékmenetet. Próbáltuk megelőzni a káoszt, amely az előző verzióban a feladatok párhuzamos megoldása miatt alakult ki. Az eredeti történetszálhoz képest végrehajtottunk változtatásokat. Erre részint a helyszín miatt, részint az első teszt során kibukó „logikátlanság” miatt volt szükség. 
Mivel a játékot csapatban játszották és nem egyénileg, az eredetileg elképzelt főszereplő karakterünk szerepét igazából senki sem tudta felvenni. A játékélmény szempontjából haszontalanná vált. A fő rejtély része az első verzióban még „személyazonosságunk” kiderítése is volt, az újban csupán egy felhasználónév és egy jelszó megfejtése maradt. A történetszálból elhagytuk egy „nem játékos karakter” - az ellenállás ügynökének megjelenését is. Korlátoztuk az infokommunikációs eszközök használatát is. A játékosokat a belépéskor „kasztokba” osztottuk. Volt egy „brigádvezető”, „informatikus”, és „dolgozó”. Segítséget csak a brigádvezető kérhetett. Infokommunikációs eszközöket csak az „informatikus” kezelhette. A történet szerint a hálózathoz csupán egy szabadon használható hozzáférési pont létezik. A játék során ez a lehetőség a brigádvezetőn kívül szabadon átruházható másra, de ugyanannál a személynél kétszer nem lehet. A játék területén plusz „hozzáférési kódot” rejtettünk el, így, ha ügyesen játszottak, a végére már 2 személy használhatott informatikai eszközöket. A kasztok jelzését az egyszerűség kedvéért színes műanyag csipeszekkel jelöltük. A játékban több irodalmi művet felhasználtunk, de nem a művek cselekményének ismerete volt a lényeges. Ebből kifolyólag nem befolyásolta a játékélményt, ha valaki még nem olvasta, esetleg csak filmen látta a művet. A játékot igyekeztünk humorosra megalkotni, ezzel is oldani a feldolgozott művek olykor negatív hangulatát. A feladatok alapvetően nem voltak nehezek. Inkább az információkeresésre helyeztük a hangsúlyt. A Nagy Testvér mindent lát elvet kissé dramatizálva és hangsúlyosabbá téve, megpróbáltuk a résztvevőket lehető legjobban megfigyelni.

\section{1. ábra: Megfigyelés alatt}

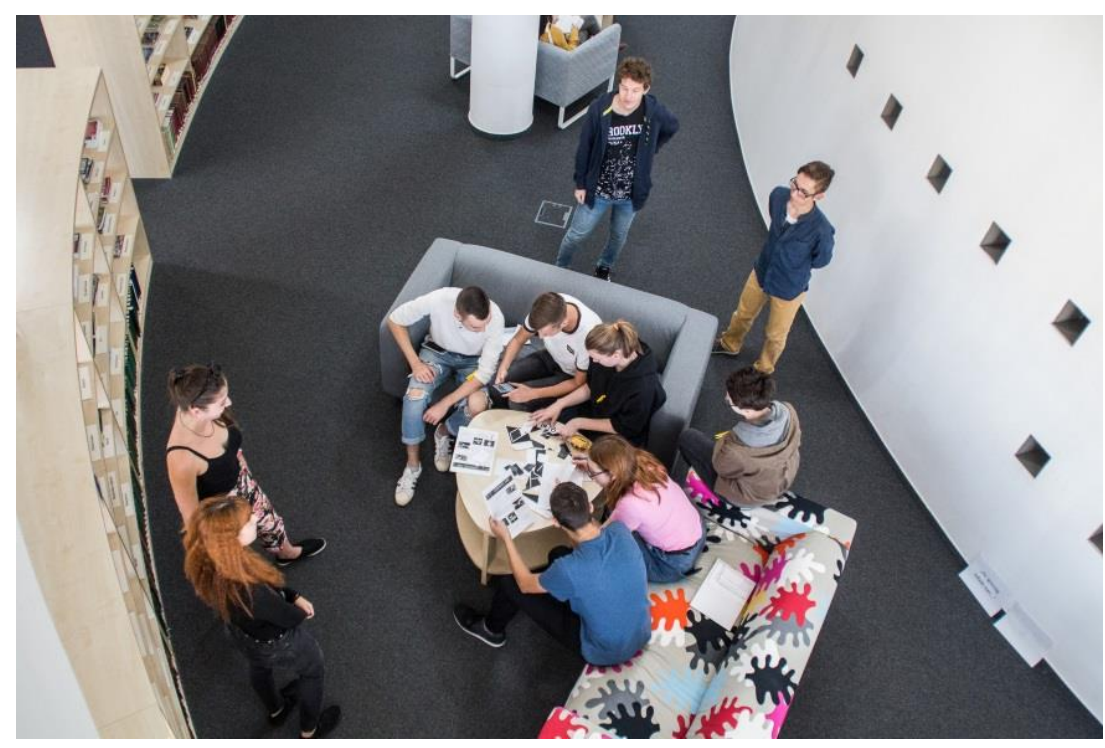

Fotó: Kóczián Zoltán Gergely

Néztük a játékosok minden mozdulatát, követtük őket. Olykor ezt szóvá is tették a résztvevők, frusztráló volt a számukra. Erre a módszerre azért volt szükség, hogy ellenőrizni tudjuk, hogy valóban a szabályoknak megfelelően oldották-e meg a feladatokat, illetve felelősséggel is tartoztunk, hiszen sokuk nem volt beiratkozott olvasó. 


\section{2. ábra: Családi csapat a Tudásközpontban}

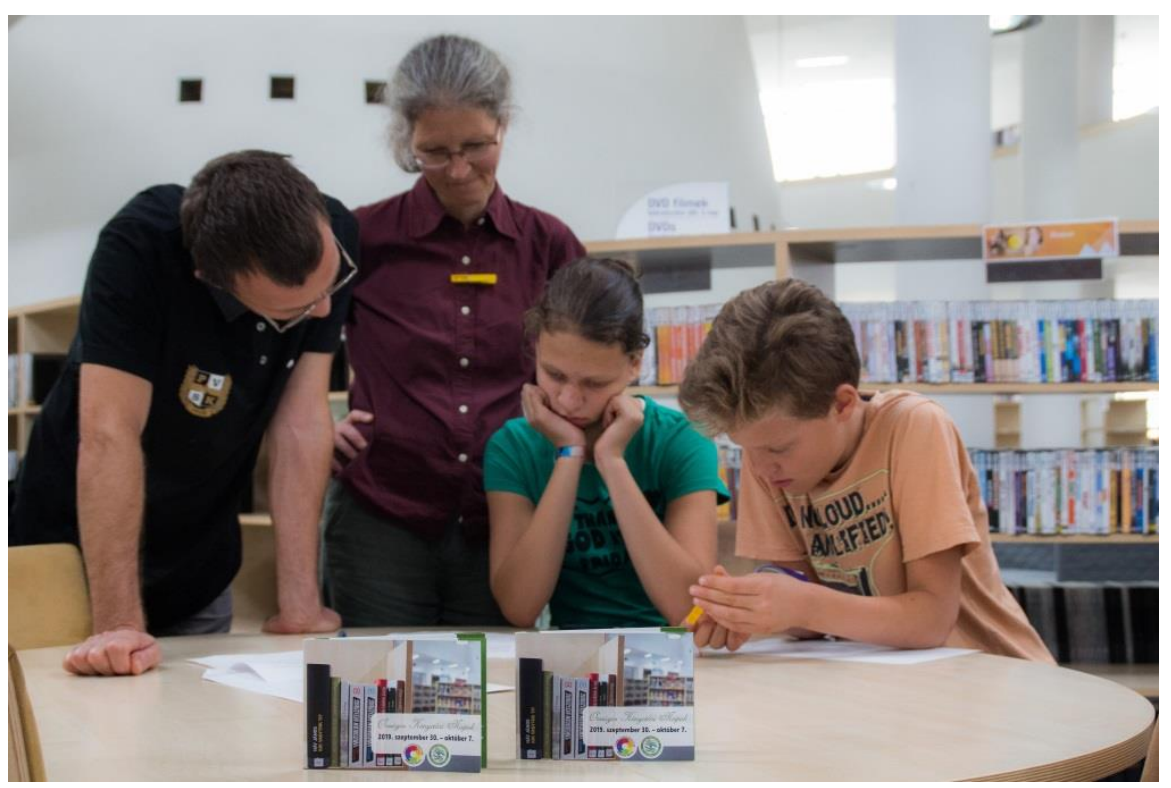

Fotó: Kóczián Zoltán Gergely

Nehézség volt, hogy a Csorba Győző Könyvtárban a program ideje alatt működtek a könyvtári szolgáltatások. Látogatók olvastak, kölcsönöztek, tanultak. Folyamatosan azon izgultunk, hogy az „érintett műveket”, nehogy elvigyék, illetve, hogy az elrejtett feladatok nehogy eltűnjenek. Igyekeztünk úgy bonyolítani a játékot, hogy ne zavarjuk az olvasókat és a könyvtárosokat.

Az Országos Könyvtári Napokon meghirdetett programokra öt fős csapatokban lehetett jelentkezni. Természetesen volt olyan, amikor több vagy kevesebb fővel érkezett egy csapat. Az eredmények kimutatták, hogy a csapat létszáma, vagy a csapattagok életkora nem befolyásolja a játékban nyújtott teljesítményt. Egy nagyobb létszámú csapat nem ér el törvényszerűen jobb időt. Az összeszokott csapatok jobban teljesítettek, az adhoc szerveződő társaságok esetében mindig nehezebben ment a csapatmunka. Látszott, hogy voltak olyan csapatok is, akik csak és kizárólag csak a tanárok által motivációként beígért jobb érdemjegyek reményében látogattak el a rendezvényre. Érezhetően voltak olyan csapattagok is (középiskolások), akik életükben először jártak a Tudásközpontban. Egy iskolából, de akár egy osztályból is érkezett több csapatra való játékos. Így megdöbbenve tapasztaltuk, hogy mekkora különbségek vannak az egyének és a csapatok szintjén is a játék megoldásához, a kijutáshoz szükséges kompetenciák tekintetében.

Alapvetően középiskolásoknak hirdettük meg a játékot, de a hét során több korosztály is képviselte magát. Voltak egyetemisták (BA hallgatók); volt egy négy tagú család és egy idősebb, 60-as éveik felé járó csapat. A feladatokat az egyetemisták oldották meg leghamarabb. Míg a második legjobb idő tulajdonosa egy 12. osztályos csapat lett. A harmadik helyen az egyik családi csapat végzett. 2019. decemberében újra játszottuk a játékot. A Nagy Testvér Figyel! tematikát adaptáltuk a Mikulás tematikához. A kérdések egy részébe a Mikulás kultuszára utaló, azzal kapcsolatos információmorzsákat rejtettünk el. Ezek tipikusan azon kérdéseknél működtek, ahol számnevek, vagy egy-egy szó volt a megfejtés. 
3. ábra: A Csapatok eredményei a két játékban

Eredeti verzió

\begin{tabular}{|c|c|c|c|c|c|}
\hline Csapatnév & Idő & Korosztály & Létszám & Lány & Fiú \\
\hline Szörnyűek & 31,41 perc & PTE-BTK BA & 5 & 5 & - \\
\hline les miserables & 37,57 perc & 12. osztály & 5 & 5 & - \\
\hline NT-TEAM & 42,00 perc & $\begin{array}{l}\text { Családi } \\
\text { csapat }\end{array}$ & 4 & 2 & 2 \\
\hline Anonimok & 42,05 perc & 11. osztály & 5 & - & 5 \\
\hline Tripladisznók & 43,00 perc & $\begin{array}{c}\text { 10. osztály } \\
\text { (Baráti társaság) }\end{array}$ & 3 & 3 & - \\
\hline Baranyai Bikák & 43,26 perc & 12. osztály & 5 & 1 & 4 \\
\hline Tripla60-asok & 44,10 perc & $\begin{array}{l}\text { Baráti } \\
\text { társaság }\end{array}$ & 6 & 6 & - \\
\hline Lányokok & 44,22 perc & 12. osztály & 5 & 5 & - \\
\hline A csoport & 44,47 perc & 12. osztály & 6 & 3 & 3 \\
\hline Barbárok & 45,00 perc & 12. osztály & 6 & 6 & - \\
\hline CSILLÁMPÓNIK & 45,00 perc & 11. osztály & 6 & 5 & 1 \\
\hline
\end{tabular}

Összesen:

56

Mikulásos verzió

\begin{tabular}{|c|c|c|c|c|c|}
\hline Csapatnév & Idő & Korosztály & Létszám & Lány & Fiú \\
\hline \hline Duplapluszjó & 36,28 perc & $\begin{array}{c}\text { Baráti } \\
\text { társaság }\end{array}$ & 6 & 2 & 4 \\
\hline $\begin{array}{c}\text { Almost } \\
\text { Phinished }\end{array}$ & 36,48 perc & PhD hallgatók & 5 & 5 & - \\
\hline $\begin{array}{c}\text { Te vagy a } \\
\text { főnök! }\end{array}$ & 45,45 perc & $\begin{array}{c}\text { Baráti } \\
\text { társaság }\end{array}$ & 3 & 2 & 1 \\
\hline K.J.A.M.N. & 50,22 perc & $\begin{array}{c}\text { Családi } \\
\text { csapat }\end{array}$ & 5 & 3 & 2 \\
\hline
\end{tabular}

Összesen:

19

Forrás: Társadalmi Befogadás Szakkollégium belső dokumentáció, 2018

Összesen tehát 15 csapatot, 75 főt tudtunk 2019-ben bevinni a könyvtárba. 5 oktatási intézményből érkezett a 10 csapatnyi tanuló. (Beleértve az egyetemistákat is.)

\section{Tapasztalatok}

Ahogy azt már jeleztük, meglehetősen eltérőek voltak az egyéni kompetenciák. Mégis megfogalmazhatunk „általános” jelenségeket az információkereséssel kapcsolatosan. A játékosok gyakran csak szemmagasságban kerestek, ezért, ha az adott mű például az alsó polcok valamelyikén volt, vagy magasabban, akkor sokkal tovább tartott a megtalálása. A résztvevők nem voltak teljesen tisztában a polcokon található jelzetekkel, sokszor gondot okozott az egyébként nagyszerűen kitáblázott ABC követése is. Az angol nevű íróknál pedig könnyen abba a hibába estek, hogy keresztnév alapján keresték a szerzőt. 
Tipikusnak mondható, hogy a középiskolás korosztály tagjai mindent az interneten szeretnének azonnal megtalálni, azon belül is a Wikipédián. Ezzel nem is lenne baj, de a Wikipédia asztali és mobilos megjelenítése között különbségek vannak, s használhatóság szempontjából az utóbbi bizonyult „lassabbnak”. Bizonyos típusú információt sokkal könnyebben lehet megtalálni akkor, ha kinyitjuk az egyébként orrunk előtt lévő könyvet. Keresési stratégiát szinte soha nem alkalmaztak a résztvevők, volt, aki a teljes kérdést beírta a Google keresőjébe. Egyértelműen látszik, hogy a korosztály számára a természetes nyelven való keresés lenne a megfelelőbb. Noha tisztában vannak vele, hogy kulcsszavak, tárgyszavak alapján kellene keresniük. Bizonyos feladatoknál az asszociációs különbségek is előjöttek. Nem csak generációs, de kulturális, szubkulturális okokat is feltételezhetünk. Azonos korcsoporton belül sem mindenki ismerte például az egyébként nagy népszerűségnek örvendő Trónok harca sorozat egyik karakterét, vagy a L'art pour L'art társulat Besenyő Pista bácsijában sem ismerték fel az egyébként író-költő, dalszerzőként is működő Laár Andrást. Mindezt természetesen befolyásolhatta az, hogy a csapattagok közül ki volt otthon a mainstream kultúra területén, s ki volt esetleg valamilyen ellenkultúra tagja, aki esetleg elvből elutasítja a nagy népszerűségnek örvendő alkotásokat. Másik oldalról nézve: többen meglepődtek azon, hogy a könyvtárban új könyvek is vannak, nem csak az unásig olvasott kötelezők, s hogy a viszonylag kortárs minőségi képregények is megtalálhatóak. A feladatokat igyekeztünk úgy elrejteni, hogy minél több dokumentumtípussal találkozzanak, illetve, hogy bejárják a Csorba Győző Könyvtár ezen állományának teljes szabadpolcos részét. Még a Kaptár kis ablakaira is ragasztottunk feladatot.

4. ábra: Nézz át a túloldalra - az igazság odaát van!

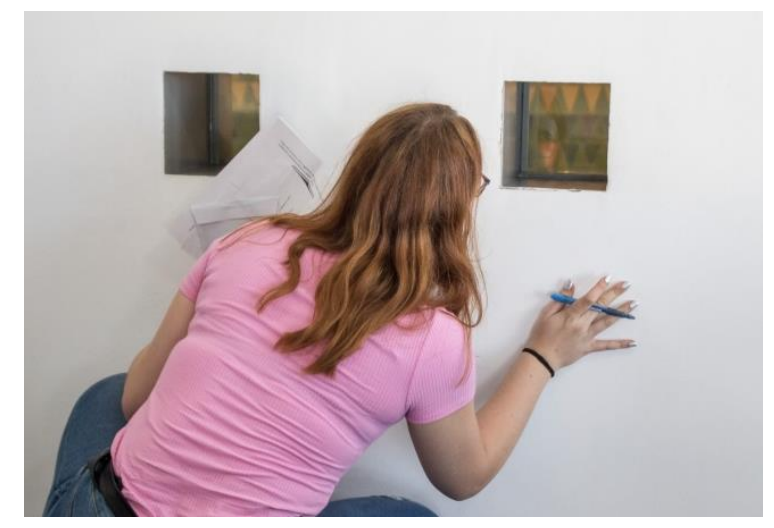

Fotó: Kóczián Zoltán Gergely

A játék végén az informatikai eszközök használata került előtérbe. Egy erre készített program segítségével kellett „feltörniük” a Nagy Testvér informatikai rendszerét. A visszajelzések alapján bár ez volt a legunalmasabb és leglassabban megoldható feladat, sokakban mégis megmaradt. Valóban elhitték, átélték, hogy egy igazi rendszert törnek fel. Ezt nagyban segítette a DOS-os időket idéző parancssoros, retró hangulatú hackerprogram és a szimulált chat-beszélgetés. Természetesen - ahogy a valóságban is itt is bizonyos formai hibák esetén „újraindult” a rendszer. Ha a játékos elvétette a parancs szintaktikáját, időt vesztett. Megfigyelhető volt, hogy sokszor figyelmetlenül gépeltek, 
vagy egész egyszerűen összekeverték a felhasználónevet és a jelszót. A játék ezen része kifejezetten azt volt hivatott „tesztelni”, hogy mit kezdenek egy olyan informatikai rendszerrel, aminek a szabályait nem ismerik, s eltér a megszokottól. Túl azon, hogy a diákok esetleg jól szórakoztak, több résztvevőnél is megfigyelhető volt, hogy a játék végére sokkal magabiztosabban mozgott a könyvtári térben. Talán önszántukból is bemerészkednek legközelebb. Tanárnőiknek írt beszámolóikból kiolvasható, hogy többet kaptak a programtól, mint amire számítottak, sőt, maguk is szívesen készítenének ilyen szabadulószobát. Véleményem szerint ezzel sikert lehetne elérni a diákok tudásszintjének növelésében.

\section{Összegzés}

2019-ben a Társadalmi Befogadás Szakkollégium és a Csorba Győző Könyvtár közös projektjeként megvalósult könyvtárhasználati szabadulószoba sikeresnek mondható. 15 csapatot, összesen 75 főt vonzott be a könyvtárba, a legkülönfélébb korcsoportokból. Talán rávilágítottunk olyan hibákra akár az offline, akár az online információkeresést illetően, amelyet a résztvevők a program után már tudatosabban, célozottabban tudnak javítani. A játék végén tartott csoportos interjúkból kiderült, hogy sokkal élvezetesebb lenne a diákok számára ez a fajta interaktív műfeldolgozás, mint egy normál tanóra.

Az általunk kidolgozott módszer közkönyvtári környezetbe bármikor adaptálható, szakkönyvtári környezetbe is, de ott a gyűjtemény speciális volta miatt picit nehezebben. Megvalósíthatósága olcsó, mert a könyvtár meglévő állományára épít. A könyvtár adja a játékteret, így nem szükséges külön „díszlet”, mint a klasszikus szabadulószobákban. Az eredeti ötletet kétszer adaptáltuk. Először 2019 decemberében egy Mikulásos verzióra, majd 2020-ban ennek mintájára egy komolyzenei tematikájú programot is összeállítottunk Papp Veronikával. A COVID járvány sajnos nem tette lehetővé a projekt érdemi folytatását.

\section{Irodalomjegyzék}

Béres J. (szerk.). (2019). A könyvtárhasználat és az információkeresés fejlesztése. Budapest: Szabó Ervin Könyvtár. https://mek.oszk.hu/20600/20683/20683.pdf Letöltés dátuma: 2020.10.26.

Coombs, P.H, Prosser, R.C., \& Ahmed, M. (1973). New Paths to Learning: For Rural Children and Youth. Essex, Connecticut: International Council for Educational Development.

Csík T. (2018). A könyvtárhasználat - információkeresés könyvtári tanításának keretei. Könyv és Nevelés. 20. (4), 85-110. http://epa.oszk.hu/03300/03300/00016/pdf/EPA03300_konyv_es_neveles_2018_4_085110.pdf Letöltés dátuma: 2020.10.26.

Csík T. (2020). Könyvtár és iskola: tanulmányok. Budapest: ELTE-BTK Könyvtár és Információtudományi Intézet. https://doi.org/10.21862/978-963-489-189-5

Csíkszentmihályi M. (1997). Flow: az áramlat: a tökéletes élmény pszichológiája. Budapest: Akadémia Kiadó. Dippold P. (2013). Közkönyvtárak és az oktatás. Könyv és Nevelés, 15 (4), 74-84.

EU (2019) 2nd Survey of Schools: ICT in Education: Hungary Country Report. https://doi.org/10.2759/76901 Fehér J. \& Koglerné Hernádi Á. (szerk.). (2019a). Könyvtárhasználat-információkeresést fejlesztő könyvtári mintaprogramok. Budapest: Fővárosi Szabó Ervin Könyvtár.

Fehér J. \& Koglerné Hernádi Á. (szerk.) (2019b). Digitális írástudást fejlesztő könyvtári mintaprogramok. Budapest: Fővárosi Szabó Ervin Könyvtár. 
Freund T. (2006). Tanulási folyamatok és belső világunk. Magyar szemle, 15 (11-12). http://www.magyarszemle.hu/cikk/20070712_tanulasi_folyamatok_es_belso_vilagunk Letöltés dátuma: 2020. 12.11.

Fromann R. (2017). Játékoslét: a gamifikáció világa. Budapest: Typotex.

Fromann R. \& Damsa A. (2016). A gamifikáció (játékosítás) motivációs eszköztára az oktatásban. Új Pedagógiai Szemle, 2016 (3-4), 76-81. URL: https://folyoiratok.ofi.hu/uj-pedagogiai-szemle/a-gamifikaciojatekositas-motivacios-eszkoztara-az-oktatasban Letöltés dátuma:2019.12.11.

Hajdu Á. \& Béres J. (szerk.).(2019). A digitális kompetencia fejlesztése a könyvtárakban. Budapest: Fővárosi Szabó Ervin Könyvtár.

Hermann Z. (2020, április 2). Hány diákhoz nem jut el az online távoktatás? Közgazdaság-és Regionális Tudományi Kutatóközpont Közgazdaság-tudományi Intézete. https://www.mtakti.hu/koronavirus/hanydiakhoz-nem-jut-el-az-online-tavoktatas/12769/ Letöltés dátuma: 2020.10.26.

Internet Live Stats (2020, október 27). https://www.internetlivestats.com/ Letöltés dátuma: 2020.10 27.

Koller I. Zs. (2019). A laboratory for community learning - the Vision of Tomorrow Workshop series. In Németh, B. (ed.). Between Global and Local: Adult Learning and Communities Network: Learning and Living in Diverse Communities (77-84). Pécs: University of Pécs.

Koltay T. (2016). Médiaműveltség, digitális bennszülöttek. A mítoszok vége? Iskolakultúra, 26 (1), 102-109. Mérei F. \& Szakács F. (1975). Csoportdinamika. Válogatás Kurt Lewin müveiből. Budapest: Közgazdasági és Jogi Könyvkiadó.

Mérő L. (2010). Az érzelmek logikája. Budapest: Tericum.

Prensky, M. (2001). Digital Natives, Digital Immigrants Part 1, On the Horizon, 9 (5), 1-6. https://doi.org/10.1108/10748120110424816

Társadalmi Befogadás Szakkollégium (2018). Belsố dokumentáció. Pécs: Pécsi Tudományegyetem, Bölcsészet-és Társadalomtudományi Kar.

Tóth M. (2015). Könyvtár és közösség. Budapest: Argumentum.

Tóth-Mózer Sz. (2013). A gyermekkép az információs társadalom hajnalán. In Ollé J. et al. (szerk.). Oktatásinformatikai módszerek: tanítás és tanulás az információs társadalomban (31-56). Budapest: ELTE Eötvös Kiadó.

Ugváry R. és Vajda E. (2002). Könyvtári információkeresés. Budapest: Typotext.

Varga K. (2008). Az információs műveltség fogalma az európai és Európán kívüli kultúrákban. In Varga K. (szerk)., A 21. század mûveltsége. E-könyv az információs mûveltségről. Pécs: PTE FEEK Könyvtártudományi Intézet. https://mek.oszk.hu/06300/06355/html/03.htm Letöltés dátuma: 2020.12.11.

Varga K. (2013). Az információtól a müveltségig: Az információs müveltség alapjai. Budapest: L'Harmattan. Varga K. (2014). Az információs múveltség fejlesztése: A könyvtárak szemléletváltása és feladatai a 21. században (pp.1-13). In NETWORKSHOP 2014. Budapest: NIIF - Nemzeti Információs Infrastruktúra Fejlesztési Intézet. http://nws.niif.hu/ncd2014/docs/ehu/048.pdf Letöltés dátuma: 2019.10.26.

Wenger, E. (1998). Communities of Practice Learning Meaning and Identity. Cambridge: Cambridge University Press.

Z. Karvalics L. (2012). Információs kultúra, információs múveltség - egy fogalomcsalád értelme, terjedelme, $\begin{array}{llllll}\text { tipológiája és története. Információs Társadalom, } 12 & \text { (1), 7-43. }\end{array}$ http://www.eltereader.hu/media/2013/11/Olle2_okt-inform_READER.pdf Letöltés dátuma: 2020.10.26. Zurkowski, P. G. (1974). The information service environment relationships and priorities. Related paper. No. 5. Washington, D.C.: National Commission on Libraries and Information Science. https://files.eric.ed.gov/fulltext/ED100391.pdf Letöltés dátuma: 2020.10.26. 